\title{
Re-imagining Citizenship, Re-imagining Social Work: U.S. Immigration Policies and Social Work Practice in the Era of AZ SB1070
}

\author{
Hye-Kyung Kang
}

\begin{abstract}
The literature on immigrant cultural citizenship (Ong, 1996; Rosaldo, 1997) has argued that traditional and normative definitions of citizenship ignore various forms of civic participation and belonging and fails to capture the experiences of immigrants in an increasingly globalized world (Getrich, 2008), calling for more nuanced and multiple meanings of citizenship. As agents of civil society, social workers have much power in constructing and maintaining (or resisting) normative discourses of citizenship, and how we participate in this process has material consequences for those we serve. Applying poststructural and postcolonial theories, this paper excavates discourses of exclusion and inequity that produce the idea of U.S. citizenship through a critical historical analysis of key U.S. immigration and naturalization-related policies and proposes immigrant cultural citizenship as a conceptual frame for re-imagining social work practice with immigrants.
\end{abstract}

Keywords: Cultural citizenship, immigration policies, postcolonial theories, social work practice with immigrants.

\section{INTRODUCTION: DISCOURSES OF CITIZENSHIP}

Citizenship, as the Western legal and social framework for promoting individual autonomy and political democracy (Shafir, 1998), also plays a major part in distributing and restricting access to rights and resources in the U.S. For example, currently voting rights, visa restrictions, and access to work and public assistance are all tied to U.S. citizenship. However, while formal state definitions of citizenship rely on legal and policy discourses, the literature on social citizenship (e.g., Del Castillo, 2002; Marshall, 1964, 1998; Park, 2005) and cultural citizenship (e.g., Ong, 1996; Rosaldo, 1997) has argued that such definitions of citizenship ignore various forms of civic participation and belonging and fail to capture the experiences of immigrants and transnational people in an increasingly globalized world (Getrich, 2008).

Ong (1996) contends that the control of a populace of a modern society is accomplished not by a single dominant force (such as the state power) but by a complex web of relations that regulate how one is constituted as a citizen-subject and that immigrant cultural citizenship is produced through "a dual process of self-making and being-made within webs of power linked to the nation-state and civil society" (p. 738). In contrast, Rosaldo's idea of Latino cultural citizenship involves both individual and group/community level processes and is concerned with the role of human agency in establishing and claiming human, social, and cultural space by marginalized groups (Flores \& Benmayor, 1997; Rosaldo, 1997). This paper does not reconcile differences in these two models but considers the tenets of both, and immigrant cultural citizenship is understood here as encompassing "the process of negotiation and contestation through

Hye-Kyung Kang, MSW, Ph.D., is an Assistant Professor in the Smith College School of Social Work in Northampton, MA.

Copyright (C) 2012 Advances in Social Work Vol. 13 No. 3 (Fall 2012), 510-526 
which the immigrant subject is produced within the constraints of the nation-state and civil society, and the practices through which immigrants create and claim their social, political, and cultural space in the society” (Kang, 2010, p. 26).

Through a critical historical analysis of key U.S. immigration and naturalizationrelated policies, this paper examines five interacting clusters of binaries (white/nonwhite; desirable/undesirable; native-born/foreigners; safe/dangerous; deserving/ undeserving) that shaped U.S. immigration discourses to demonstrate how they ultimately construct U.S. citizenship as a discourse of exclusion and offers cultural citizenship as a more complex and inclusive conceptualization for understanding citizenship.

\section{POSTSTRUCTURAL AND POSTCOLONIAL THEORIES}

Poststructural and postcolonial theories provide the theoretical framework and inform the method of this paper. Poststructural theories maintain that social realities and subject positions (such as "citizens" and "race") are produced through discourses (Fairclough, 1992; Foucault, 1972, 1975, 1982) but that discourses are partial, privileging one version of social reality over others and promoting a version of social subjects (e.g., "undesirable immigrants")—one that both defines and establishes what is supposedly "true" at particular moments (Carabine, 2001). Furthermore, discourses are mutable and dynamic - as are the subject positions produced by them - and contingent upon their social, political and historical contexts (Fairclough, 1992; 1995).

In extending this discursive construction of subjects (Foucault, 1972, 1975, 1982), postcolonial theorists such as Hall (1996) and Bhabha (1994) propose that while subjects may not be able to escape the effects of the discourses that construct them (e.g., essentializing discourses), they still can resist and even alter them (Ashcroft, Griffiths, \& Tiffin, 2000). One effective way in which postcolonial theories open up such opportunities is by calling into question the binary system (e.g., legal/illegal) in dominant social discourses (Ashcroft et al., 2000). They argue that the binary oppositions are not merely two opposing signs but entail "a violent hierarchy, in which one term of the opposition is always dominant," and that "the binary opposition itself exists to confirm that dominance" (Ashcroft et al., 2000, p. 24). One unavoidable problem of the binary system is that the social reality must fit neatly into dual oppositions; the ambiguity inherent in an interstitial state threatens it by exposing its contradictions (Bhabha, 1994). By illuminating these contradictions (e.g., biracial in the white/non-white binary system of race), postcolonial theories expose how this system perpetuates relations of cultural, social, economic and political dominance and open up possibilities for hybridity (Bhabha, 1994) and change.

Guided by poststructural and postcolonial theories, this paper uses a critical discourse analysis method (Fairclough, 1992, 1995) to illustrate how subject positions, such as "immigrants" and "citizens," were produced and transformed through legal and policy discourses over time and illuminates binary oppositions that resulted in promoting citizenship as a system of exclusion. 


\section{DISCURSIVE CONSTRUCTION OF CITIZENSHIP}

In the U.S., citizenship is a legal status that may be achieved in three ways. The first path qualifies those who are born on the U.S. soil. The second path is open to those who are born to parents who are U.S. citizens (e.g., children who were born overseas to a U.S. citizen parent). The third path is through naturalization. Currently, immigrants who have a legal resident status may apply to become naturalized citizens after 5 years (or 3 years for the spouses of U.S. citizens) of continuous residency. However, these paths to U.S. citizenship - and their attendant rights and access to resources - have been paved with racialization and inequities. In fact, a review ${ }^{1}$ of key U.S. immigration and naturalizationrelated policies ${ }^{2}$ illustrates how these constructed who was "American" and who would be worthy of becoming a citizen of this country, based on a set of interrelated binaries such as white/non-white; desirable/undesirable; native-born/foreigners; deserving/ undeserving; safe/dangerous. Together and repeatedly, these discourses construct immigrants as the binary opposite "other" to the U.S. citizens "norm."

\section{Making of a Racialized (Non)Citizen: White/Non-white; Desirable/Undesirable}

One example of "violent hierarchy" in colonial ideology (and its attendant contradictions) is the idea of race, which is based on the white/non-white binary opposition in the United States (Lowe, 1996; Mills, 1997). Historically, the construction of race as a white/non-white binary has never presented these two terms as equals nor resulted in equitable treatment (Hing, 2004; Lopez, 1996; Ngai, 2005). This construction of race consolidates great variances within ethnicities (both white and non-white) and cultural traditions while prohibiting racial mixing between whites and non-whites (e.g., anti-miscegenation laws). As detailed in a later section, the race prerequisite cases demonstrate that any experience or state that did not fit the white/non-white binary opposition was rendered suspicious and was repressed and silenced through legal and policy discourses. Because the white/non-white binary is not only significant in its role in shaping the nation's racial landscape but also is implicated in - and complicates-all other binaries, this binary will be analyzed in more detail than others to illustrate the mechanism of discursive construction of citizenship through policies.

Before the 1790 Naturalization Act, the U.S. naturalization process was largely based on the Asylum Principle, which is famously echoed in Emma Lazarus's 1883 poem, The New Colossus: "[...] Give me your tired, your poor./ Your huddled masses yearning to breathe free [...]." While magnanimous, this principle was not applied to everyone, nor did it bring those who were already in this land (Native Americans) through the "golden door" of U.S. citizenship. In fact, European migration to America resulted in near decimation of the indigenous population (Stannard, 1992; Takaki, 1993). Until 1790, it was assumed that immigrants to the U.S. would be granted U.S. citizenship, as there were no specific federal regulations regarding it. It is notable that before that, most immigrants had come from Western Europe; however, after that the Naturalization Act restricted U.S. citizenship to "free white persons." This Act, the nation's first policy regarding naturalization, was also the first national Act to limit naturalization rights based on the idea of race (white) and status (free). The designation "white" is especially important because the incipient idea of race, and specifically who was considered "white," was 
beginning to be constructed through both scientific and social discourses of that era (Lopez, 1996; Mills, 1997; Omi \& Winant, 2007). By privileging one category ("white”) over others, and granting them the right to naturalize, this naturalization policy became part of a discourse that constructed binary and unequal meanings of race in the U.S. Furthermore, this Act began codifying the link between the idea of race and the idea of citizenship.

\section{Racializing Naturalization}

In this section, immigration and naturalization-related policies targeting Asian immigrants are used to illustrate the racialized discourse of citizenship based on the white/non-white binary. (The history of Latino immigrants also represents the similar point. However, for the sake of brevity, this paper uses the history of Asian immigrants as an illustrative focus.) Asian immigrants represent both the undesirable "other" and the exposed ambivalence in the white/non-white binary discourse of race. After the discovery of gold in California in 1849, Chinese laborers were actively recruited and brought to the U.S. in large numbers to work in the gold mines and on the transcontinental railroad construction. Once considered an essential labor force, Chinese workers laid an estimated $90 \%$ of the railroad tracks (Takaki, 1993). However, Chinese laborers quickly became a target of malicious exclusionary laws once white laborers started moving to the West and saw them as economic competitors (Takaki, 1993). National, state, and local laws during the Gold Rush era established Asian immigrants as undesirable foreigners, as the economic and labor needs of the nation shifted (Chin, 2001; Hing, 2004; Takaki, 1993). Also, Chinese immigration presented a threat to the white/non-white binary system as their racial position was somewhat ambiguous in the still-incipient system of the U.S. racial taxonomy. This threat would be silenced through a series of court cases.

One of the landmark cases that determined Chinese immigrants' place within the white/non-white binary construction of race was the People v. Hall case. In 1854, the California Supreme Court ruled that Chinese could not give testimony against white people in Court. The ruling was an extension of California Criminal Procedure's existing (1850) exclusion, "No black or mulatto person, or Indian, shall be allowed to give evidence in favor of, or against a white man" (Lopez, 1996, p. 51). The California Supreme Court declared:

We are of the opinion that the words "White," "Negro," "Mulatto," "Indian," and "Black person," wherever they occur in our Constitution and laws, must be taken in their generic sense, and that, even admitting the Indian of this Continent is not of the Mongolian type, that the words "Black person," in the 14th section must be taken as contradistinguished from White, and necessarily excludes all races other than the Caucasian. (California Supreme Court, 1854, italics added)

This case not only contributes to constructing Chinese (or the "Mongolian type") as non-white but also defines the existing categories through an exclusionary binary logic. Furthermore, it is the idea of the "impassable difference" [of] "a distinct people, [...] a race of people whom nature has marked as inferior" (California Supreme Court, 1854) on 
which the Court based its opinion to declare them undesirable to participate in society as citizens.

During the Civil War, the Emancipation Proclamation (1863) effected changes that resulted in the Naturalization Act of July 14, 1870, extending the right to naturalize to "aliens" of African nativity and to persons of African descent. This Act, however, did not dismantle the race-based exclusions of the 1790 Act or change the discourse of citizenship as based on the white/non-white binary. Instead, it upheld such exclusion by simply adding African Americans to the list of those who were eligible for naturalization. Asians and other people of color were still excluded from such rights. In fact, the proceedings from the Circuit Court case in 1878 regarding Ah Yup, a Chinese immigrant, reveals that the makers of this Act expressly sought to block from citizenship the Chinese (and by extension, all Asians, as the Chinese were being denied the naturalization rights on the grounds that they belonged to the "Asiatic" or "Mongolian" race, which, the Court argued, was distinct from the "Caucasian” race):

At that time of the amendment, in 1870, extending the naturalization laws to the African race, Mr. Sumner made repeated and strenuous efforts to strike the word "white" from the naturalization laws, or to accomplish the same object by other language. It was opposed on the sole ground that the effect would be to authorize the admission of Chinese to citizenship. Every senator, who spoke upon the subject, assumed that they were then excluded by the term "white person," and that the amendment would admit them, and the amendment was advocated on the one hand, and opposed on the other, upon that single idea. (Sawyer, 1878, in Lopez, 1996, p. 211)

In this case, the Circuit Court ruled that Chinese were not white, and thus were ineligible for citizenship, using two major discourses: congressional intent (explained above) and scientific. The scientific discourse was used to argue that the Chinese were considered to be of the "Mongolian race," and therefore could not be considered "white," according to the contemporary anthropological classifications (Lopez, 1996). This argument used these anthropological classification systems not necessarily to determine who was white but to disprove that Chinese, specifically, were white. The case of Ah Yup was the first of many racial prerequisite cases to continue this intertextual trend, thereby determining the meaning of race by disproving who may or may not be considered "white" and eligible or ineligible for naturalization. Lopez (1996) lists 52 such racial prerequisite cases from 1878 to 1944, revealing the complex and intimate connection between the construction of race and the construction of citizenship in the U.S. Two of the most influential of those cases, Ozawa v. United States and United State $v$. Thind, will be discussed later in this section.

Since Asians were considered to be non-white through the legal cases and in the eyes of the civil society, their immigration posed a potential threat to maintaining the racial composition of the country. Although African Americans were given the rights to naturalize, there was no sizable migration from Africa during the post-Civil War era. Thus, Asian immigration was one of the most important potential sources of non-white migration. The immigration laws following the Ah Yup case illustrate how Asians were 
targeted as undesirable immigrants, in opposition to and reinforcing the construction of white Europeans as desirable immigrants. For example:

- The Chinese Exclusion Act (1882): The first immigration act to ban immigration and naturalization of a population based solely on nationality. Suspended immigration by all Chinese laborers for ten years and specifically barred the Chinese from naturalization.

- The U.S. Circuit Court in Massachusetts (1894): Declared that the Japanese were also ineligible for naturalization.

- $\quad$ The Act of March 3, 1887: Restricted real estate ownership to American citizens and barred Asians from owning land.

- The Scott Act (1888): Prohibited the re-entry of Chinese laborers who left the U.S. to visit families and homeland, effectively stranding them, and reducing the number of Chinese in the U.S.

- $\quad$ The Act of April 29, 1902: Extended Chinese Exclusion Act indefinitely. ${ }^{3}$

- The Act of February 5, 1917: Prohibited immigration from the "barred zone," which designated most of eastern Asia and Pacific Islands. The first national Act to exclude whole populations based on their geographic locations and, presumably, race.

The 1920s brought highly specific race-based (white/non-white) and ethnicity-based (desirable/undesirable) restrictions on immigration, which solidified the linkage between race, ethnicity and citizenship. In 1921, the Quota Law was enacted, limiting admissions from each European country to 3\% of each foreign-born nationality in the 1910 census and upholding Asia as a "barred zone." Since the U.S. population in 1910 was predominantly Western and Northern European, the quota for Southern and Eastern Europeans was only about 45,000 out of 350,000 total immigrants per year (Hing, 2004), and there would be no growth through immigration in the number of Asians and Pacific Islanders. Three years later, the Johnson-Reed Act (the Immigration Act of May 26, 1924) extended this law and established the official national origins quota system, which based the immigration numbers on the ethnic makeup of the U.S. population as a whole in 1920, determining the future ethnic pattern of the nation. ${ }^{4}$

The quota system was lauded as a major accomplishment that halted "the tendency toward a change in the fundamental composition of the American stock" (Hing, 2004, p. 69). Judging from the 1920 census, what was meant by "the fundamental composition" seems plain: predominantly Western European (Hing, 2004). The Quota Law and the Johnson-Reed Act, as they assigned the number of allowable immigrants based on their nationality, betrays the stability of the white/non-white; desirable/undesirable paring of the binaries. They assigned different degrees of desirability to different nationalities, implying that not all Europeans were equally desirable even if they were considered white. In fact, scholars such as Brodkin (1998) and Ignatiev (1995) argued that only through the exclusion of people of color did more marginalized (i.e., the "less desirable," such as Irish, Jewish, Italian) Europeans come to be constructed as "white." Thus, this 
law reveals not only the specific coupling of ethnicity and race with the citizenship but also the hierarchy (desirable/undesirable) therein.

Two of the most influential racial prerequisite cases in this era are Ozawa v. United States and United State v. Thind. In 1922, the U.S. Supreme Court ruled that Mr. Takao Ozawa, a Japanese immigrant, could not be naturalized because he was not white. In this case, the Court rejected Mr. Ozawa's argument of “white” skin pigmentation and of his cultural assimilation and allegiance to the U.S. Instead, the Court determined that persons of Japanese ancestry, regardless of their skin tone or their cultural practices, were not white because "only persons of what is popularly known as the Caucasians race" (Lopez, 1996, p. 79) were white. Therefore, in this case, the word "white" was equated with the modern anthropological category "Caucasian." Just three months later, in 1923, the Supreme Court rejected this equation in U.S. v. Bhagat Singh Thind. In this case, Mr. Thind, an immigrant from India, argued that he was white because anthropologists classified Asian Indians not as "Mongolians" but as "Caucasians" (Lopez, 1996). However, the Supreme Court determined that Mr. Thind could not be considered white (and therefore could not be naturalized), even though the anthropological classification system - the very basis on which Mr. Ozawa's case was rejected-would place him within the category, "Caucasian." The U.S. Supreme Court ruled that:

What we now hold is that the words 'free white persons' are words of common speech, to be interpreted in accordance with the understanding of the common man, synonymous with the word 'Caucasian' only as that word is popularly understood," [and that the words of the statute were] written in the words of common speech, for common understanding, by unscientific men. (Lopez, 1996, p. 90)

Thus, the Court abandoned the "scientific" argument for a "popular understanding" and "common speech" argument in this case. However, whether the Court used the scientific argument, the "popular understanding" argument, or the congressional intent argument (as in the Ah Yup case), what remains consistent throughout these cases is suppression of the ambivalence within the white/non-white hierarchical binary system of race. Also apparent is the insistent use of a binary discourse of white/non-white: desirable/undesirable as the rubric for exclusion.

Race- and ethnicity-based immigration restrictions started to ease after U.S. involvement in World War II. Needing to strengthen the U.S.-China relationship during the war, the Act of December 17, 1943 (the Magnuson Act) repealed the Chinese Exclusion Act, allowing Chinese to be eligible for naturalization. However, due to the Quota Law, the number of allowable immigrants from China was still miniscule. In addition, the Luce-Cellar Act of 1946 extended the right to become naturalized citizens to Filipinos and Asian Indians, but with a quota of just 100 persons per year. Finally, the Immigration and Naturalization Act of June 27, 1952 (the McCarran-Walter Act) made all races eligible for naturalization; however, it affirmed the national-quota system of 1924, limiting total annual immigration to $1 / 6$ of $1 \%$ of the population of the continental U.S. in the 1920s. In the end, these post-war provisions did little to change the racial and 
ethnic landscape of the U.S. citizenship or the discourse of exclusion, but rather were used as a token to assuage the U.S. relationship with its wartime allies.

It was not until the enactment of the Immigration and Nationality Act of 1965, reflecting the changing national discourse about race, rights, and democracy (e.g., the Vietnam War controversy, the civil rights movement, and the ensuing civil rights legislations), that the national origins quotas were finally eliminated. This Act gave immigration priority to family reunification instead of the numerical restrictions based on national origins. It had a profound impact on immigration since it finally allowed immigration from the countries that had been barred or underrepresented under the Johnson-Reed Act. In fact, data from the U.S. Immigration and Naturalization Services indicate that the majority of immigrants who entered the U.S. since the 1965 Act have been people of color (United States Department of Homeland Security, 2009), thus effecting changes in the overall population patterns of the nation. These shifts illustrate how changing discourses of race, equity, and politics (domestic and international) interact with changing discourses of citizenship.

\section{Citizenship as Restriction: Native-born/Foreign; Safe/Unsafe; Deserving/ Undeserving}

While U.S. citizenship is celebrated as granting various rights (U.S. Citizen and Immigration Services), it has also been used to restrict those rights. This section illustrates how binary constructions such as native-born/foreign; deserving/undeserving; safe/dangerous in immigration and naturalization laws excluded immigrants from their rights as citizens of a society. When these binaries intersect with the white/non-white binary these laws produce a highly inequitable version of citizenship.

\section{Restricting Immigrants' Access: Native-Born/Foreign; Deserving/Undeserving}

The laws in this section illustrate how immigration policies constructed unequal citizenship through deserving/undeserving discourses. Often coupled with the nativeborn/foreign binary, these laws barred undesirable immigrants from entering the country, restricted their access to resources and resulted in a severely bifurcated system of citizenship.

The Immigration Act of August 3, 1882, which established a system of central control of immigration through State Boards under the Secretary of Treasury (thus implying immigration as an economic issue), also broadened the definition of "inadmissible aliens" by barring "persons likely to become a public charge." This law not only constructs immigrants as a potential drain to public resources (such as governmentor private-funded charities) but also establishes the line between the deserving (nativeborn) and the undeserving (foreign).

The 1891 Immigration Act, the first comprehensive law for national control of immigration, added to the list of undesirables ineligible for immigration: "persons suffering from a loathsome or a dangerous contagious disease," and those convicted of "a misdemeanor involving moral turpitude.” Targeting newer immigrants from Southern and Eastern Europe, who had started migrating in larger numbers, as well as immigrants from 
Asia (Takaki, 1993), this law contributed to a long and enduring construction of ethnicized and racialized immigrants as morally inferior and as public health problems (Park \& Kemp, 2006). Furthermore, this policy again stabilized the unequal discourse of citizenship based on the coupling of the native-born/foreign and deserving/undeserving binaries where immigrants faced exclusion from benefits even if they had the same conditions as did their citizen counterparts.

This discourse reverberates in contemporary policies as well. In 1994, California passed Proposition 187, which stipulated that public agencies should deny services to undocumented immigrants ("illegal immigrants") and report them to the Immigration and Naturalization Services (INS). It also cut government benefits to noncitizens (regardless of their legal status). In 1996, the Personal Responsibility and Work Opportunity Reconciliation Act (PRWORA) established severe restrictions on the eligibility of legal immigrants for means-tested public assistance. Under this law, legal immigrants were barred from receiving public assistance that their taxes helped pay for. Given the fact that the majority of immigrants in the recent years have been people of color, this law also meant that the public benefits were barred from these immigrants of color where similar benefits were allowed for the immigrants of earlier eras, who were predominantly from Europe. Thus, this law illustrates the ways in which white/non-white, native-born/foreign, and deserving/undeserving binaries interact to produce harsh inequality. Together, these acts construct immigrants (especially immigrants of color) as undeserving subjects.

\section{Restricting Immigrants' Rights: Native-Born/Foreign; Safe/Dangerous}

The laws in this section illustrate the ways in which the native-born/foreign binary interacts with the safe/dangerous binary to curb immigrants' rights in the name of national security. The Alien and Sedition Act of 1798 provides the first example of coupling immigration with national security, constructing immigrants as a potential threat to the safety of the nation. This law authorized the president to deport any foreigner deemed to be dangerous and made it a crime to speak, write, or publish anything "of a

false, scandalous and malicious nature” about the President or Congress. As a result, it reduced immigrants' rights to free speech (which had been created by the Bill of Rights just nine years before), while their citizen counterparts were able to fully enjoy such rights, creating a bifurcated (native-born/foreign) construction of citizenship.

The Immigration Act of March 3, 1903, reiterated this construction. Following the assassination of President McKinley, it became the first measure to exclude aliens on the grounds of proscribed opinions (e.g., "anarchists"). The Alien Registration Act of June 28, 1940, further solidified the construction of immigrants as a potential danger to the national security as it required the registration of all aliens and fingerprinting of those over age 14 for the first time.

The national security argument to take away the rights of immigrants reached its peak in 1942 when Executive Order No. 9066 was enacted, forcing an internment of 120,000 Japanese immigrants and Japanese Americans (Takaki, 1993). The fact that the internment targeted Americans of Japanese ancestry but not Italian or German immigrants reveals the underlying discrimination based on race (white/non-white). This 
policy illustrates how the national security discourse interacted with the race discourse to construct Japanese Americans (regardless of their place of birth or legal citizenship status) as perpetually foreign and therefore dangerous.

The Immigration Reform and Control Act of 1986, which was passed in order to control and deter illegal immigration to the U.S., echoed this construction. While this law was to increase enforcement at U.S. borders, most of the increase was geared toward the Mexican (signifying non-white) border, rather than the Canadian (signifying white) border (Ngai, 2005). By singling out the Mexican border as a risk to national security, this law again solidifies the non-white-foreign-dangerous link.

The national security discourse became intensified in the 2000s. After the 9/11 attacks, the Homeland Security Act (2002) made the INS part of the Homeland Security Department, formally subsuming immigration under national security. Thus, this law positions immigrants as potential national security problems (instead of as a source of labor or possible solution for the declining national population, for example). Detaining and/or expelling foreign-born individuals became easier under the Patriot Act (2001), and many suffered unjust deportation and/or detention. While it was not written in a racespecific language, this Act nevertheless became infamous for its racial-profiling consequences, as many immigrants of color were harassed and detained because they were presumed to be Middle Eastern (ACLU, 2004). These laws illustrate the ways in which binary discourses such as white/non-white, native-born/foreign, and safe/dangerous converge to construct immigrants as a risk to national security and also to restrict civil rights.

\section{Current Implications: The Mutable and Enduring Legacy of the Inclusion/ Exclusion Binary}

In the 2000s, immigration increased, particularly from Asia and south of the U.S. border, triggering waves of nativism and derailing federal efforts to enact immigration reform. Between 2005 and 2007, fifty-five localities passed anti-housing, antiemployment, or English-only initiatives (J. Garcia, personal communication, 07/01/2008), particularly aimed at Latino immigrants. This wave of contemporary local anti-immigrant initiatives culminated in Arizona's Senate Bill (SB) 1070, which was signed into law (the Support Our Law Enforcement and Safe Neighborhoods Act) by Arizona Governor Jan Brewer, on April 23, 2010. This law, commonly referred to as AZ SB 1070, has many broad and controversial implications too numerous to fully summarize here (ACLU, 2010) and is currently being debated publically and contested legally in various courts. Two of the most divisive issues revolve around the following sections:

Sec. 2. B. For any lawful contact made by a law enforcement official or agency of this state or a county, city, town or other political subdivision of this state where reasonable suspicion exists that the person is an alien who is unlawfully present in the United States, a reasonable attempt shall be made, when practicable, to determine the immigration status of the person. 
Sec. 3. A. In addition to any violation of federal law, a person is guilty of trespassing if the person is both: 1 . Present on any public or private land in this state. 2. In violation of 8 United States code section 1304(e) or 1306(a). ${ }^{5}$

Section 2B not only gives local law enforcement officers and agencies the authority to enforce federal immigration laws but also uses such broad language as "reasonable suspicion,” raising concerns about potential racial/ethnic profiling. Section 3A essentially makes it a misdemeanor for immigrants to be in the State of Arizona without carrying their alien registration documents at all times, sparking a critique that it will result in civil rights violations and harassment of immigrants as well as citizens.

Fueled by anxiety over demographic changes, economic uncertainties and reports of increased drug trafficking and violence in Mexico (Archibold \& Steinhaur, 2010), this law not only reprises the white/non-white, desirable/undesirable, native-born/foreign, deserving/undeserving, and safe/dangerous binaries that constructed many exclusionary policies of the past but also highlights the ambivalence within these narratives. For example, the Hispanic population in Arizona reached 30\% in 2010 (up from 25\% in 2000 ), and proponents of this law raised concerns about threats to the maintenance of an idealized Anglo-American culture (Huntington, 2004), echoing earlier sentiments behind the Nationalization Act of 1790, the Ah Yup case in 1878, the Johnson-Reed Act of 1924, and many other Acts based on white/non-white and desirable/undesirable binaries. While this law does not explicitly mention race, an Arizona police officer, Martin Escobar, argued in his lawsuit against the state that there were no race-neutral criteria to suspect someone was an "illegal immigrant" and that the only way to enforce this law was to interrogate people who visibly looked Hispanic (i.e., non-white) (Smith, 2010). Proponents also argued that undocumented immigrants weakened the economy and took away scarce resources, echoing deserving/undeserving narratives, such as the Immigration Act of August 3, 1882, and more recently the California Proposition 187 in 1994 and the Personal Responsibility and the Work Opportunity Reconciliation Act of 1996. Finally, fear of an increase in crime and violence was often cited as the main reason for this policy, reflecting the native-born/foreign and safe/dangerous binaries of the Alien and Sedition Act of 1798, and more recently the Immigration Reform and Control Act of 1986, the Homeland Security Act of 2002 and the Patriot Act of 2001. However, there has been no evidence that the crime rate has risen with an increased presence of immigrants (Archibold \& Steinhaur, 2010); in fact, Sampson's (2008) study indicates that immigration seems to reduce violent crime rates. By repackaging these binaries (white/non-white; desirable/undesirable; native-born/foreign; deserving/ undeserving; safe/dangerous) into a legal/illegal binary framework, AZ SB 1070 consolidates contradictions within them.

This review of the major immigration and naturalization policies from 1790s to early 2000s illustrates how these policies constructed who was "American" and who was worthy of becoming a citizen. It also reveals that the binary frameworks are ultimately about exclusion/inclusion, which demands suppression of contradictions, tension and ambivalence within the very idea of citizenship. They obscure underlying racism, political exigencies, and competing economic interests that are deeply implicated in immigration and naturalization policy discourses. 


\section{DISCUSSION: IMPLICATIONS FOR SOCIAL WORK PRACTICE}

Social workers contribute, wittingly and unwittingly, to the production, maintenance, and change of the discourse of citizenship through their work in all levels (micro, mezzo, macro) of practice. As such, they should use their power as agents of civil society mindfully and critically. Immigrant cultural citizenship as a conceptual frame may help social workers to critically evaluate the normative narratives of citizenship and help immigrants resist such discourses and claim their social and cultural space.

As illustrated in the previous section, U.S. immigration and naturalization policy discourses have constructed and maintained a binary version of citizenship that produced egregious and persistent inequities. The binary construction of realities is of a particular relevance for social workers. On the one hand, social workers are operating in a world of binary realities made up of agency policies, state eligibility guidelines, and diagnostic criteria with which they assess their clients. On the other hand, social workers function within the most complex and irreducible contexts that constitute people's lives. These coexisting realities demand that social workers become critical in their appraisal of normative realities and their consequences.

When social workers unquestioningly embrace a binary construction of reality, they risk perpetuating the "violent hierarchy" of the binary system that may result in colonizing and dominating people's experiences. As many postcolonial writers stress, while the military and the imperial governments conquered nations and enforced oppressive imperialist rules, the "benevolent missionaries, teachers, administrators, and social workers - educated persons united in their desire to help in various ways those defined as in need of assistance, guidance, and protection" (Rober \& Seltzer, 2010, p. 124) colonized peoples' minds and subjugated their lifeworlds (Summerfield, 2004) by upholding hegemonic discourses around health, rights and citizenship that resulted in pathologizing differences and normalizing social injustice. Similarly, simply by accepting dominant policies and procedures, social workers can easily become agents of social surveillance and discipline. Certainly, more severe examples such as the involvement of U.S. social workers in the cultural displacement of the Native children through the Indian Adoption Project of the 1950s (Hair \& O'Donohue, 2009) demonstrate the iatrogenic effects of accepting the truncated realities prescribed by government policies. Thus, unless social workers actively engage in a critical analysis of such inequitable discourses as citizenship and immigration, they continue to act as a disciplining force to uphold inequitable normative narratives and to reinforce injustice on immigrant subjects. In interrogating such narratives, social workers may uncover binary positioning of subjects that subjugate the experiences and lives of immigrants and restrict their access to equitable resources. For example, contesting the dominant discourse of the legal/illegal binary construction and changing the language from "illegal aliens" to "undocumented immigrants" radically shifts the positionality, discourses, and options for immigrants.

The historical analysis in the previous section also demonstrates that the idea of citizenship is far from monolithic or stable, and that immigration and naturalization policies reflect many changes experienced by the nation, both internally and internationally. These changes tell us that the idea of citizenship can be contested, 
negotiated, and is, ultimately, changeable. In fact, immigrant individuals, groups, and communities are actively engaged in practices that contest, resist, and negotiate the very discourses that construct them as the "other" and place them in inequitable positions. For example, the racial prerequisite cases discussed in the previous section represent the ways in which immigrants of various ethnic backgrounds attempted to contest the unequal access to naturalization rights by calling into question the binary construction of race (white/non-white) on which such rights were based. The cases such as Korematsu $v$. United States [1944] and Yick Wo V. Hopkins [1886] demonstrate immigrants' demands for equal protection and legal rights, as national and local laws violated their civil and economic rights (Nakanish \& Lai, 2003). Immigrant labor movements such as the Farmworkers Movement in California in the 1960s (Delloro, 2009), the Filipino Cannery Workers Movement in Alaska in the 1970s (Chin, 2001), the garment industry workers' labor organizing in Los Angeles in the 1990s (Lowe, 1996), and domestic workers' organizing in New York in the 2000s (Sen, 2010) further exemplify the ways in which immigrant groups organized themselves to contest the unequal narratives of labor rights and to negotiate space for themselves in the nation's economic landscape. Most recently, the Dream Act inspired a powerful movement by undocumented young people where they deconstructed the very discourse (immigration and naturalization laws) that had produced them as noncitizens by engaging in civil disobedience, political advocacy, organizing, and other rights of citizenship (Hing, 2010).

Learning from these examples, social workers who work with immigrants must actively generate interventions that embrace multiple narratives, resistance, and negotiations. By contemplating the process of discursive production, maintenance, and change, they may reach beyond the usual adjustment (i.e., adjustment of the immigrant "person" to the "environment" of the host society and its civic and governmental disciplinary forces) narrative of intervention and actively assist in and foster opportunities for all immigrants to claim their social, political, and cultural places in the society. Conceptualizing the process of immigrant cultural citizenship not only as an individual process but also as a collective process enables social workers to consider interventions that go beyond the usual individual acculturation-centered paradigm and offer opportunities for collective interventions that change the discourses. ${ }^{6}$

In today's turbulent and divisive immigration debates, social workers have an opportunity to make an important impact. The recent passage of AZ SB 1070 produces immigrant subjects as less than human by prohibiting humane treatment for undocumented immigrants. Thus, this policy attempts to force social workers to either submit to the disciplinary powers of the law (and deny services to those in need) or to stand with the disadvantaged, risking discipline under the law. However, such moral dilemmas ensue only if social workers accept these normative discourses as a stable authority. The concept of immigrant cultural citizenship reminds social workers that they can resist and contest such constructions that attempt to colonize not only the lives of immigrants but also their practice as social workers. ${ }^{7}$ Only when they begin to question the very discourses that produce them will they start the process of decolonizing and creating change. 
${ }^{1}$ Since they are influenced by slightly different political reasons, refugee-related policies are not included in this review.

${ }^{2}$ Unless otherwise noted, all immigration and naturalization policies discussed here are based on Lemay \& Barkin (1999).

${ }^{3}$ However, an exception was made so that Chinese laborers would be able to enter Hawaii, which was forcibly annexed by the U.S. in 1898 and needed workers to work on its plantations that were owned by Americans. This exception exemplifies the ambivalence of the legal discourse as the nation deals with different political and economic exigencies. Although Hawaii was a territory of the U.S., it was not part of the mainland and did not have the full status and rights of a U.S. state. In addition, since there were few white laborers competing for jobs in Hawaii, the Chinese presence in this newly acquired territory did not pose a problem in terms of balancing the political and economic exigencies of the nation.

${ }^{4}$ The quota system, however, did not apply to Asian immigration since this law denied entry to virtually all Asians, which meant that the Asian population could fall even below the rate of what it was in 1920. The same law also prevented Chinese women from rejoining their husbands in the U.S., thereby further curbing Chinese population growth.

${ }^{5}$ This clause refers to the federal laws that require certain immigrants to register with the U.S. government and to have the documents in possession at all time.

${ }^{6}$ For example, the Kang (2011) case study examines how applying postcolonial conceptual frames such as immigrant cultural citizenship helped immigrant clients to produce their own counter-narratives, which contested inequitable immigration and welfare policies and created alternative meanings of citizenship.

${ }^{7}$ In fact, the National Association of Social Workers (NASW) demonstrated this resistance when it released a public statement to express its strong opposition to AZ SB1070 (NASW, 2010).

\section{References}

American Civil Liberties Union. (2004, Feb. 26). Racial profiling since 9/11 report. Retrieved from http://www.aclu.org/national-security/racial-profiling-911-report

American Civil Liberties Union. (2010, May 18). ACLU of Arizona section by section analysis of SB 1070 "immigration; law enforcement; safe neighborhoods" as amended by HB 2162. Press release. Retrieved from http://acluaz.org/SectionBySectionAnalysisSB1070UPDATED51810.pdf

Archibold, R. C., \& Steinhauer, J. (2010, April 29). Welcome to Arizona, outpost of contradictions. The New York Times: A14. Retrieved from http://www.nytimes.com/2010/04/29/us/29arizona.html

Ashcroft, B., Griffiths, G., \& Tiffin, H. (2000). Post-colonial studies: The key concepts. London \& New York: Routledge.

Bhabha, H. K. (1994). The location of culture. London: Routledge.

Brodkin, K. (1998). How Jews became white folks and what that says about race in America. New Brunswick, NJ: Rutgers University Press. 
California Supreme Court. (1854). People v. Hall 4 Cal. 399. Retrieved from http://www.uchastings.edu/racism-race/people-hall.html

Carabine, J. (2001). Unmarried motherhood 1830-1990: A genealogical analysis. In M. Wetherall, S. Taylor, \& S. J. Yates (Eds.), Discourse as data: A guide for analysis (pp. 267-307). London: Sage.

Chin, D. (2001). Seattle's International District: The making of a Pan-Asian American community. Seattle, WA: International Examiner Press.

Del Castillo, A. (2002). Illegal status and social citizenship: Thoughts on Mexican immigrants in a postnational world. Aztlán, 27(2),11-32.

Delloro, J. (2009, March 31). Cesar Chavez day and the forgotten Asian Americans. Retrieved from http://www.laprogressive.com/rankism/cesar-chavez-day-and-theforgotten-asian-americans/

Fairclough, N. (1992). Discourse and social change. Cambridge, UK: Polity Press.

Fairclough, N. (1995). Critical discourse analysis: The critical study of language. UK: Longman Group Limited.

Flores, W. V., \& Benmayor, R. (1997). Constructing cultural citizenship. In W. V. Flores \& R. Benmayor (Eds.), Latino cultural citizenship (pp.1-23). Boston, MA: Beacon Press.

Foucault, M. (1972). The archaeology of knowledge and the discourse on language. New York: Pantheon Books.

Foucault, M. (1975). Discipline and punish: The birth of the prison. New York: Vintage Books.

Foucault, M. (1982). The subject and power. In H. Dreyfus \& P. Rabinow (Eds.), Michel Foucault: Beyond structuralism and hermeneutics (pp. 208-228). Chicago: University of Chicago Press.

Getrich, C. M. (2008). Negotiating boundaries of social belonging: Second-generation Mexican youth and the immigrant rights protests of 2006. American Behavioral Scientist, 52, 533-556.

Hall, S. (1996). Introduction: Who needs "identity"? In S. Hall \& P. du Gay (Eds.), Questions of cultural identity (pp.1-17). London: Sage.

Hair, H., \& O’Donohue, K. (2009). Culturally relevant, socially just supervision: becoming visible through a social constructionist lens. Journal of Ethnicity and Cultural Diversity in Social Work, 18(1-2), 70-88.

Hing, B. O. (2004). Defining America through immigration policy. Philadelphia: Temple University Press.

Hing, J. (2010, Dec. 20). How undocumented youth nearly made their DREAMs real in 2010. Retrieved from http://colorlines.com/archives/2010/12/dream_movement_profile.html 
Huntington, S. P. (2004, March 1). The Hispanic challenge. Foreign Policy. Retrieved from http://www.foreignpolicy.com/articles/2004/03/01/the hispanic challenge

Ignatiev, N. (1995). How the Irish became white. New York: Routledge.

Kang, H.-K. (2010). Cultural citizenship and immigrant community identity: Constructing a multi-ethnic Asian American community. El Paso, TX: LFB Scholarly Publishing LLC.

Kang, H.-K. (2011). Claiming cultural citizenship: The case of Mrs. Moon. Unpublished manuscript.

Lazarus, E. (1883). The new colossus. Retrieved from http://en.wikipedia.org/wiki/The_New_Colossus

LeMay, M. C., \& Barkan, E. R. (Eds). (1999). U.S. immigration and naturalization laws and issues: A documentary history. Westport, CT: Greenwood Press.

Lopez, I. H. (1996). White by law: The legal construction of race. New York and London: New York University Press.

Lowe, L. (1996). Immigrant acts. Durham, NC: Duke University Press.

Marshall, T. H. (1964). Class, citizenship, social development: Essays. Garden City, NY: Doubleday.

Marshall, T. H. (1998). Citizenship and social class. In G. Shafir (Ed.), The citizenship debates (pp. 93-111). Minneapolis, MN: University of Minnesota Press.

Mills, C. W. (1997). The racial contract. Ithaca, NY: Cornell University Press.

Nakanish, D. T., \& Lai, J. S. (Eds.). (2003). Asian American politics: Law, participation and policy. Lanham, MD: Rowman \& Littlefield Publishers, Inc.

National Association of Social Workers. (2010). NASW opposes Arizona Immigration Law. Retrieved from http://www.socialworkers.org/practice/intl/2010/042910.asp

Ngai, M. M. (2005). Impossible subjects: Illegal aliens and the making of modern America. Princeton, NJ: Princeton University Press.

Omi, M., \& Winant, H. (2007). Racial formation. In P. Rothenberg (Ed.), Race, class, and gender in the United States ( $7^{\text {th }}$ ed., pp. 13-22). New York: Worth Publishers.

Ong, A. (1996). Cultural citizenship as subject-making: Immigrants negotiate racial and cultural boundaries in the United States. Current Anthropology, 37(5), 737-762.

Park, L. S.-H. (2005). Consuming citizenship: Children of Asian immigrant entrepreneurs. Palo Alto, CA: Stanford University Press.

Park, Y., \& Kemp, S. P. (2006). “Little Alien Colonies”: Representations of immigrants and their neighborhoods in social work discourse, 1875-1924. Social Service Review, 80(4), 705-734. 
Rober, P., \& Seltzer, M. (2010). Avoiding colonizer positions in the therapy room: Some ideas about the challenges of dealing with the dialectic of misery and resources in families. Family Process, 49(1), 123-137.

Rosaldo, R. (1997). Cultural citizenship, inequality, and multiculturalism. In W. V. Flores \& R. Benmayor (Eds.), Latino cultural citizenship (pp. 27-38). Boston, MA: Beacon Press.

Sampson, R. J. (2008, Winter). Rethinking crime and immigration. Contexts. Retrieved from http://contexts.org/articles/winter-2008/sampson/

Sen, R. (2010, Sept. 2). Domestic workers lead the way to 21st century labor rights. Retrieved from http://colorlines.com/archives/2010/09/domestic_workers_lead_the_way_toward_21s t_century_labor_rights.html

Shafir, G. (Ed.). (1998). The citizenship debates. Minneapolis, MN: University of Minnesota Press.

Smith, D. (2010, April 29). Tucson cop files federal suit against AZ immigration law. Tucsonsentinel.com. Retrieved from http://www.tucsonsentinel.com/local/report/042910 ecobar 1070/tucson-cop-filesfederal-suit-against-az-immigration-law/

Stannard, D. (1992). American holocaust: The conquest of the new world. New York: Oxford University Press, Inc.

State of Arizona. (2010). Arizona Session Laws, Chapter 113, Forty-ninth Legislature, Second Regular Session: Senate Bill 1070. Retrieved from http://www.azleg.gov/FormatDocument.asp?inDoc=/legtext/49leg/2r/laws/0113.htm

Summerfield, D. (2004). Cross-cultural perspectives on the medicalization of human suffering. In G. M. Rosen, (Ed.), Posttraumatic stress disorder: Issues and controversies (pp. 233-245). Chichester, West Sussex, UK: John Wiley \& Sons, Ltd.

Takaki, R. (1993). A different mirror: A history of multicultural America. New York: Back Bay Books.

United States Department of Homeland Security. (2009). Immigration Statistics. Retrieved from http://www.dhs.gov/files/statistics/immigration.shtm

\section{Author note:}

Address correspondence to: Hye-Kyung Kang, Assistant Professor, Smith College School for Social Work, Northampton, MA 01063. Email: hkang@smith.edu 